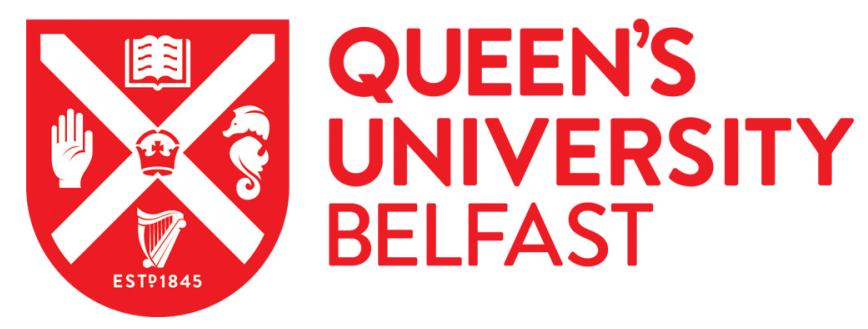

\title{
Metabolic syndrome and coronary heart disease risk in a population- based study of middle-aged men from France and Northern Ireland
}

Bataille, N. V., Perret, B., Dallongeville, J., Arveiler, D., Yarnell, J., Ducimetiere, P., \& Ferrieres, J. (2006).

Metabolic syndrome and coronary heart disease risk in a population-based study of middle-aged men from France and Northern Ireland. Diabetes Metab, 32(5), 475-479.

Published in:

Diabetes Metab

Queen's University Belfast - Research Portal:

Link to publication record in Queen's University Belfast Research Portal

\section{General rights}

Copyright for the publications made accessible via the Queen's University Belfast Research Portal is retained by the author(s) and / or other copyright owners and it is a condition of accessing these publications that users recognise and abide by the legal requirements associated with these rights.

Take down policy

The Research Portal is Queen's institutional repository that provides access to Queen's research output. Every effort has been made to ensure that content in the Research Portal does not infringe any person's rights, or applicable UK laws. If you discover content in the Research Portal that you believe breaches copyright or violates any law, please contact openaccess@qub.ac.uk. 


\title{
Metabolic syndrome and coronary heart disease risk in a population-based study of middle-aged men from France and Northern Ireland
}

\section{A nested case-control study from the PRIME cohort}

\author{
V Bataille ${ }^{1}$, B Perret ${ }^{2}$, J Dallongeville ${ }^{3}$, D Arveiler ${ }^{4}$, J Yarnell ${ }^{5}$, P Ducimetière ${ }^{6}$, J Ferrières ${ }^{1}$
}

\section{S U M M A R Y}

Metabolic Syndrome (MetS) was found associated with an increased CHD risk in several studies but data about this relationship in Southern Europe are lacking. We studied the association of MetS according to three different indexes (the National Cholesterol Education Program's definition (NCEP), a modified World Health Organization's definition (WHO) and the recent International Diabetes Federation's definition (IDF)) with CHD risk in a case-control study nested within the PRIME cohort, composed of subjects from France (Southern Europe) and Belfast (Northern Europe).

The PRIME prospective study is composed of 10592 men, aged 50-59 at baseline and followed for 5 years. Subjects included in this nested case-control study were 296 cases of incident $\mathrm{CHD}$ and 540 controls, who remained free of CHD during the 5 years of followup of the PRIME cohort and matched for age, recruitment centre and recruitment date. All subjects had questionnaires and a medical examination at baseline, and a blood sample was taken.

Using the IDF's, the WHO's and the NCEP's definitions respectively, the frequency of MetS was 38.9\%, 35.5\% and $29.7 \%$ in cases and $32.4 \%$, $28.7 \%$ and $22.6 \%$ in controls. After adjustment for physical activity, smoking and drinking habits, MetS was associated with $\mathrm{CHD}$ risk whichever the definition used $\left(O R_{\mid D F}=1.41\right.$ [1.02-1.95], $P<0.04$,

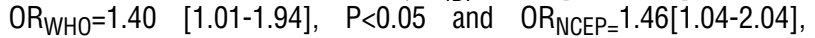
$\mathrm{P}<0.04$ ). These results were homogeneous in France (low risk of CHD) and Belfast (high risk of CHD).

Our results add further evidence that MetS is predictive of $\mathrm{CHD}$ risk in middle-aged men from Northern and Southern Europe, and highlight differences between the three definitions studied.

Key-words: Metabolic Syndrome · CHD Risk · Male · Middle-aged · Prospective.

Bataille V, Perret B, Dallongeville $\mathrm{J}$, Arveiler $\mathrm{D}$, Yarnell J, Ducimetière $\mathrm{P}$, Ferrières J. Metabolic syndrome and coronary heart disease risk in a population-based study of middle-aged men from France and Northern Ireland. A nested case-control study from the PRIME cohort Diabetes Metab 2006;32:475-479

\footnotetext{
1 INSERM U558, Department of Epidemiology, CHU-Toulouse, France

${ }^{2}$ INSERM U563, Department of Biochemistry, La Grave Hospital,

CHU-Toulouse, France

${ }^{3}$ Pasteur Institute, Lille, France

${ }^{4}$ Department of Epidemiology and Public Health, Louis Pasteur University, Strasbourg, France

${ }^{5}$ Department of Epidemiology and Public Health, Queen's University-Belfast, UK

${ }^{6}$ INSERM U 258, Brousse Hospital, Villejuif, France.
}

R É S U M É

Syndrome métabolique et risque coronaire chez l'homme d'âge moyen en France et en Irlande du Nord. Étude cas-témoins issue de la cohorte PRIME

Une association syndrome métabolique (SM) - risque de maladie coronarienne a été trouvée dans plusieurs études mais cette relation est peu décrite dans des études épidémiologiques prospectives menées en Europe du Sud. Dans cette étude, la relation entre risque de maladie coronaire et SM, défini selon 3 définitions différentes (la définition du National Cholesterol Education Program (SMNCEP), la définition modifiée de l'OMS (SMOMS) et la définition récemment proposée par l'International Diabetes Federation (SMIDF)) a été étudiée dans une étude cas-témoin enchassée dans l'étude de cohorte PRIME, menée conjointement en France et en Irlande du Nord.

La cohorte PRIME est composée de 10592 hommes, âgés de 50 à 59 ans à l'inclusion et suivis pendant 5 ans. L'effectif de notre étude cas-témoins intra-cohorte était composé de 296 cas incidents de maladie coronaire (infarctus du myocarde ou angor) et de 540 témoins, demeurés indemnes de maladie coronaire durant les 5 ans de suivi de la cohorte PRIME, et appariés pour l'âge, le centre et la date d'inclusion. À l'inclusion, tous les sujets ont été invités à remplir des questionnaires, ont été examinés et ont subi un prélèvement sanguin.

En utilisant respectivement la définition IDF, la définition OMS et la définition NCEP, la fréquence du SM était de 38,9\%, 35,5\%, et 29,7\% chez les cas, et de $32,4 \%, 28,7 \%$, et 22,6 \% chez les témoins. Après ajustement sur l'activité physique, la consommation d'alcool et la consommation de tabac, le SM était associé au risque de maladie coronaire quelle que soit la définition utilisée $\left(O R_{S M I D F}=1,41[1,02-1,95]\right.$, $\mathrm{P}<0,04,0 R_{\text {SMOMS }}=1,40[1,01-1,94], \mathrm{P}<0,05$ et $0 R_{\text {SMNCEP }}=1,46$ $[1,04-2,04], P<0,04)$. Ces résultats étaient comparables chez les sujets recrutés en France (Europe du Sud) et en Irlande du Nord (Europe du Nord).

Les résultats de cette étude menée en France et en Irlande du Nord renforcent l'hypothèse que le SM est associé au risque coronaire chez les hommes d'âge moyen et soulignent les différences entre les 3 définitions utilisées.

Mots-clés : Metabolic Syndrome - CHD Risk · Male · Middle-aged · Prospective.

Address correspondence and reprint requests to:

J Ferrières. INSERM U558, Faculté de Médecine,département d'Épidémiologie, 37, allée Jules Guesde, 31073 Toulouse cedex. France. ferriere@ cict.fr

Received: February 21th, 2006; accepted: May 30th, 2006. 


\section{Introduction}

Metabolic syndrome (MetS) has been found associated with atherosclerosis [1,2] and risk of coronary heart disease (CHD) in the United-States [3-7] or in Northern-Europe [812], where cardiovascular incidence rates are elevated. There is in contrast much less information on the relationship between MetS and CHD risk in low risk populations from Southern-Europe, where the nutritional and environmental background is more favourable. Furthermore, recently, the International Diabetes Federation (IDF) has proposed a new definition of MetS [13].

Therefore, we assessed the risk of CHD associated with $\mathrm{MetS}$ in middle-aged men from France (Southern Europe) and Northern-Ireland (Northern Europe) in a nested casecontrol study from the PRIME cohort. To this end, we used three different definitions of the MetS proposed by the IDF [13], Laaksonen et al. (modified World Heath Organisation's (WHO) definition) [14] and the National Cholesterol Education Program (NCEP) [15].

\section{Methods}

The PRIME cohort [16,17] is composed of 10592 men, aged 50-59 and free of CHD at baseline, recruited in Northern-Ireland (Belfast) and France-Lille (North), Strasbourg (East) and Toulouse (Southwest)-between 1991 and 1994. Subjects were recruited in the general population through prevention and screening centres or in industry or administration through occupational medicine channels. Globally, in the French centres, two third of the subjects were recruited through prevention centres and one third through occupational medicine. In Belfast, all subjects were recruited in industry through occupational medicine.

After signing an informed consent, each subject had questionnaires and a medical examination including standardised measures of height, weight, waist and hip circumferences and blood pressure. A blood sample was taken after a 12-h fast. Plasma for lipid measurements was prepared immediately and was sent weekly at $4^{\circ} \mathrm{C}$ to Lille for a centralised measurement at the beginning of the study. All other aliquots were stored locally at $-80^{\circ} \mathrm{C}$ and were regularly sent on dry ice to Lille for long-term storage in lowtemperature banks. High density-lipoprotein cholesterol (HDL-C) was obtained after precipitation of apoprotein-B lipoproteins by phosphotungstate acid/polyanions and measured by cholesterol esterase-cholesterol oxydase techniques. Triglycerides were measured by enzymatic methods using triglyceride-lipase and glycerol-kinase.

Data about incident cases of CHD were obtained by an annual follow-up and details were obtained from hospitals and general practitioners. Each case of CHD was validated by an independent Medical Committee composed of one member of the PRIME study group and three independent cardiologists. Details about endpoints in the PRIME study are detailed elsewhere [16]. Shortly, CHD cases in this work gathered "hard" CHD events (fatal or non-fatal myocardial infarction or coronary related death), and angina pectoris cases (defined by the presence of chest pain at rest and/or on exertion and at least one of the following criteria: angiographic stenosis over $50 \%$, positive scintigraphy (if no angiographic data), positive exercise stress test (if no angiographic or scintigraphic data), electrocardiogram changes at rest (if no angiographic, scintigraphic or exercise stress test data), but without myocardial infarction and no evidence of a noncoronary cause in the clinical history).

Follow-up was completed for $98 \%$ of the subjects after five years, during which 335 cases of CHD (175 fatal or nonfatal myocardial infarction and 160 angina pectoris) occurred. For each of these incident cases of CHD, two controls were randomly selected from the participants in the PRIME cohort who remained free of CHD over the followup, matched for age ( \pm 3 years), recruitment centre and examination date ( \pm 3 days). Therefore, the sample of this nested case-control study was composed of 1005 subjects (335 cases and 670 matched controls). Glucose and insulin were assayed using plasma samples collected at baseline, immediately frozen and stored for $7-9$ years at $-80^{\circ} \mathrm{C}$. Glucose was assayed by enzymatic methods (glucose oxydase). Insulin was assayed by a competitive radioimmunoassay (Sanofi-Diagnostic Pasteur, France). Subjects with incomplete data were excluded. If a case was excluded, his two matched controls were also excluded. If the two matched controls for a case were excluded, the corresponding case was also excluded. If one of the matched controls was excluded, both the other control and the corresponding case remained in the sample. Finally, 169 subjects were excluded, leading to a final sample composed of 836 subjects: 296 cases and 540 controls.

The IDF-defined MetS was defined by a waist circumference $\geq 94 \mathrm{~cm}$ plus any two of the four following criteria: triglycerides $>1.70 \mathrm{mmol} / 1$ (or self-reported treatment), HDL $<1.03 \mathrm{mmol} / 1$, blood pressure $\geq 130 / 85 \mathrm{mmHg}$ (or selfreported treatment), fasting plasma glucose $\geq 5.6 \mathrm{mmol} / \mathrm{l}$ (or self-reported treatment). The WHO-MetS was defined as fasting plasma glucose $\geq 6.1 \mathrm{mmol} / 1$ (or self-reported treatment) or fasting insulin $\geq 13$ IU/1 (upper quartile of the nondiabetic population in controls) associated with at least two of the following abnormalities: obesity or central obesity (BMI $\geq 30 \mathrm{~kg} / \mathrm{m}^{2}$ or WHR $>0.90$ ), dyslipidaemia (triglycerides $\geq 1.7 \mathrm{mmol} / 1$ or HDL-Cholesterol $<0.9 \mathrm{mmol} / \mathrm{l}$ ) and arterial hypertension (blood pressure $\geq 140 / 90 \mathrm{mmHg}$ or self-reported treatment). The NCEP-MetS was considered as present if at least three of the following criteria were met: waist circumference $>102 \mathrm{~cm}$, HDL-Cholesterol $<1.03 \mathrm{mmol} / 1$, triglycerides $\geq 1.70 \mathrm{mmol} / 1$, fasting plasma glucose $\geq 6.1 \mathrm{mmol} / \mathrm{l}$ and blood pressure $\geq 130 / 85 \mathrm{mmHg}$.

Tobacco consumption was self-reported and adjustment for smoking habits was performed using three classes: non- 
smoker, 1 to 10 cigarettes per day, up to 10 cigarettes per day. Self-reported alcohol consumption (number of glasses, detailed for each beverage and each day within a standard week) was used to compute the quantity of pure alcohol ingested by day (g/d). Alcohol consumption was categorised into three classes (teetotallers $(0 \mathrm{~g} / \mathrm{d})$, mean consumption within a standard week under $40 \mathrm{~g} / \mathrm{d}$ and more than $40 \mathrm{~g} / \mathrm{d}$ ). Physical activity was considered as present if at least a moderate physical activity activity of at least 20 minutes once or twice a week was reported by the subject.

$\chi^{2}$ tests were used to test differences between cases and controls. A conditional logistic regression model, enabling to take into account the matching between cases and controls, was used to assess the CHD risk associated with MetS using either of these three definitions, after adjustment for physical activity, smoking and drinking habits (Crude odds-ratios were obtained by including only the variable considered in the model).

\section{Results}

Among the 836 subjects included in this study, $44.7 \%$ were from Belfast and $55.2 \%$ from France, and the mean age at baseline was $55.2[ \pm 2.8]$.

According to the IDF's, the WHO's and the NCEP's definitions respectively, the frequency of MetS was $38.9 \%$, $35.5 \%$ and $29.7 \%$ in cases and was $32.4 \%, 28.7 \%$ and $22.6 \%$ in controls. These proportions seemed to deeply vary according to centre but differences were not statistically different neither in cases $(31.8 \%, 39.5 \%$ and $30.2 \%$ in Belfast, $58.3 \%$, $27.1 \%$ and $37.5 \%$ in Lille, $40.0 \%, 34.0 \%$ and $26.0 \%$ in Strasbourg, $37.7 \%, 34.7 \%$ and $26.1 \%$ in Toulouse) nor in controls $(29.0 \%, 31.2 \%$ and $22.9 \%$ in Belfast, $46.2 \%, 28.2 \%$ and $28.2 \%$ in Lille, $46.6 \%, 35.2 \%$ and $26.0 \%$ in Strasbourg, $20.9 \%, 18.6 \%$ and $15.5 \%$ in Toulouse) whichever the definition used.

Smoking was more frequent in cases than in controls both in the French centres $(\mathrm{P}<0.001)$ and the Belfast centre $(\mathrm{P}<0.01)$. Conversely, no significant difference was found between cases and controls for physical activity or drinking habits. In table I are summarised differences between cases and controls for each criteria contributing to the construction of the three MetS's definitions studied. WHO-defined and NCEP-defined MetS were significantly associated with $\mathrm{CHD}$ in univariate analyses $\left(\mathrm{OR}_{\mathrm{WHO}}=1.38\right.$ [1.01-1.88], $\mathrm{OR}_{\mathrm{NCEP}=} 1.45$ [1.05-2.01]), but significance was not reached for IDF-defined MetS (OR $\mathrm{ODF}_{\mathrm{IDF}} 1.34$ [0.99-1.83]).

After adjustment for physical activity, smoking and drinking habits, the OR estimates for the association of MetS with CHD ranged from 1.40 to 1.46 depending on the MetS definition and all three definitions of MetS were significantly associated with CHD (table II).

In sub-group analyses by country, the adjusted OR estimate for the NCEP-defined MetS was comparable in Belfast and in the French centres. Conversely, even if no significant difference was existing, the OR estimate obtained using the WHO-defined MetS tended to be higher in Belfast than in the French centres, while the OR estimate obtained using the IDF-defined MetS tended to be slightly higher in the French centres than in Belfast.

Further analyses by type of event showed that adjusted OR estimates for myocardial infarction, $\left(\mathrm{OR}_{\mathrm{IDF}}=1.24\right.$ [0.79-1.96] $\mathrm{P}=0.35, \quad \mathrm{OR}_{\mathrm{WHO}}=1.44 \quad[0.91-2.28] \quad \mathrm{P}=0.12$, $\left.\mathrm{OR}_{\mathrm{NCEP}}=1.71[1.05-2.78] \mathrm{P}<0.04\right)$ tended to be higher than adjusted $\mathrm{OR}$ for angina $\left(\mathrm{OR}_{\mathrm{IDF}}=1.63[1.02-2.60] \mathrm{P}<0.05\right.$, $\mathrm{OR}_{\mathrm{WHO}}=1.36[0.85-2.17] \mathrm{P}=0.20, \mathrm{OR}_{\mathrm{NCEP}}=1.29$ [0.80-2.08] $\mathrm{P}=0.30$ ), except for the IDF's definition.

\section{Discussion}

In our work, in a cohort of men aged 50-59 from France and Belfast, MetS was significantly associated with $\mathrm{CHD}$ using IDF's, WHO's and NCEP's definitions with comparable OR, independently from usual confounders such as age, physical activity, smoking and drinking habits. Conversely, the frequency of MetS was higher using the IDF's than using the NCEP's definition of MetS.

These differences may be related to three major differences between IDF's and NCEP's criteria for MetS. Firstly, in the IDF's definition, abdominal obesity is a prerequisite whereas it is one among others factors in the NCEP's definition. Secondly, the thresholds defining abdominal obesity and hyperglycaemia are lower in the IDF's definition than in the NCEP's one, leading to an increase in the proportion of subjects responding to the IDF's criteria of MetS compared with NCEP's definition. Furthermore, the lowering of these thresholds of abdominal obesity and hyperglycaemia may have resulted in the inclusion of lower risk subjects in the IDF-MetS group, therefore diluting the relationship.

However, the association we found between MetS and CHD risk, with ORs around 1.5, was not as strong as the associations reported in previous prospective studies from the United-States $[3,4,6,7]$ and Northern-Europe $[9,11,12]$ in middle-aged men, displaying a 2 or 3 -fold higher risk for subjects with MetS. Nevertheless, hazard risk estimates of 1.5 to 2 after adjustments, close to those we observed, were found in the USA in the Atherosclerosis Risk in Communities study (ARIC) [3].

Sub-group analyses reduce statistical power, but even if significance was not reached in sub-group analyses by country, these results were globally comparable in France (low risk of CHD) and Belfast (high risk of CHD).

In conclusion, our results indicate that the frequency of MetS may be higher using IDF's definition than using NCEP's one. However, IDF-defined, WHO-defined and NCEP-defined MetS were predictive of CHD risk in men in a population composed of subjects from France and Northern Ireland with comparable ORs. 
V Bataille et al.

Table I

Frequency of metabolic syndrome according to the three definitions and frequency of each criteria involved in these definitions.

\begin{tabular}{|c|c|c|c|c|c|c|}
\hline & \multicolumn{2}{|c|}{ France $(n=462)$} & \multicolumn{2}{|c|}{ Belfast $(n=374)$} & \multicolumn{2}{|c|}{ All centres $(n=836)$} \\
\hline & $\%$ & $p$ & $\%$ & $p$ & $\%$ & $p$ \\
\hline \multicolumn{7}{|c|}{ Waist circ. $>102 \mathrm{~cm}$ NCEP } \\
\hline Cases & 28 & ns & 12 & ns & 21 & ns \\
\hline Controls & 28 & & 10 & & 20 & \\
\hline \multicolumn{7}{|c|}{ Waist circ. $>=94 \mathrm{~cm}$ IDF } \\
\hline Cases & 62 & ns & 42 & ns & 53 & ns \\
\hline Controls & 55 & & 39 & & 48 & \\
\hline \multicolumn{7}{|c|}{$\mathrm{BMI}>=30 \mathrm{~kg} / \mathrm{m}^{2}$ or WHR >=0.9 wно } \\
\hline Cases & 95 & ns & 84 & ns & 90 & 0.01 \\
\hline Controls & 87 & & 79 & & 83 & \\
\hline \multicolumn{7}{|c|}{ FPG $>5.6 \mathrm{mmol} / /$ or treatment IDF } \\
\hline Cases & 28 & ns & 18 & ns & 24 & ns \\
\hline Controls & 31 & & 16 & & 24 & \\
\hline \multicolumn{7}{|c|}{$\mathrm{FPG}>=6.1 \mathrm{mmol} / \mathrm{l}$ or treatment ${ }^{\mathrm{WHO}}$} \\
\hline Cases & 19 & ns & 9 & ns & 15 & ns \\
\hline Controls & 15 & & 6 & & 11 & \\
\hline \multicolumn{7}{|c|}{$\mathrm{FPG}>=6.1 \mathrm{mmol} / \mathrm{l}^{\mathrm{NCEP}}$} \\
\hline Cases & 18 & ns & 9 & ns & 14 & ns \\
\hline Controls & 14 & & 6 & & 10 & \\
\hline \multicolumn{7}{|c|}{$\mathrm{FPG}>=6.1 \mathrm{mmol} / / \mathrm{l}$ or treatment, or fasting insulin $>=13 \mathrm{IU} / \mathrm{I}^{\mathrm{IDF}}$} \\
\hline Cases & 37 & ns & 42 & ns & 39 & ns \\
\hline Controls & 33 & & 41 & & 37 & \\
\hline \multicolumn{7}{|c|}{$\mathrm{TG}>=1.7 \mathrm{mmol} / \mathrm{l}$ or treatment ${ }^{\mathrm{IDF}}$} \\
\hline Cases & 47 & ns & 57 & ns & 51 & ns \\
\hline Controls & 40 & & 51 & & 45 & \\
\hline \multicolumn{7}{|c|}{$\mathrm{TG}>=1.7 \mathrm{mmol} / \mathrm{l}^{\mathrm{NCEP}}$} \\
\hline Cases & 37 & ns & 57 & ns & 46 & ns \\
\hline Controls & 34 & & 50 & & 41 & \\
\hline \multicolumn{7}{|c|}{$\mathrm{HDL}-\mathrm{C}<=1.03 \mathrm{mmol} / \mathrm{I}^{\mathrm{NCEP} \text { IDF }}$} \\
\hline Cases & 40 & $<0.001$ & 47 & ns & 43 & $<0.001$ \\
\hline Controls & 24 & & 40 & & 31 & \\
\hline \multicolumn{7}{|c|}{$\mathrm{TG}>=1.7 \mathrm{mmol} / \mathrm{l}$ or $\mathrm{HDL}-\mathrm{C}<=0.90 \mathrm{mmol} / \mathrm{l}$ WHO } \\
\hline Cases & 46 & ns & 63 & ns & 53 & $<0.05$ \\
\hline \multirow{2}{*}{\multicolumn{7}{|c|}{$B P>=130 / 85 \mathrm{mmHg}$ or treatment ${ }^{\mathrm{IDF}}$}} \\
\hline & & & & & & \\
\hline Cases & 76 & $<0.01$ & 70 & ns & 73 & $<0.01$ \\
\hline Controls & 64 & & 60 & & 62 & \\
\hline \multicolumn{7}{|c|}{$\mathrm{BP}>=130 / 85 \mathrm{mmHg}$ NCEP } \\
\hline Cases & 74 & $<0.03$ & 69 & $<0.04$ & 72 & $<0.01$ \\
\hline Controls & 63 & & 58 & & 61 & \\
\hline \multicolumn{7}{|c|}{$\mathrm{BP}>=140 / 90 \mathrm{mmHg}$ or treatment ${ }^{\text {WHO }}$} \\
\hline Cases & 55 & $<0.02$ & 53 & $<0.01$ & 54 & $<0.001$ \\
\hline Controls & 42 & & 38 & & 40 & \\
\hline \multicolumn{7}{|c|}{ WHO-defined MetS } \\
\hline Cases & 32 & ns & 40 & ns & 36 & $<0.05$ \\
\hline Controls & 26 & & 32 & & 29 & \\
\hline \multicolumn{7}{|c|}{ NCEP-defined MetS } \\
\hline Cases & 29 & ns & 30 & ns & 30 & $<0.03$ \\
\hline Controls & 22 & & 23 & & 23 & \\
\hline IDF-defined M & & & & & & \\
\hline Cases & 44 & ns & 32 & ns & 39 & ns \\
\hline Controls & 35 & & 29 & & 32 & \\
\hline
\end{tabular}

WHO: criterium involved in the WHO's definition of metabolic syndrome, NCEP: criterium involved in the NCEP'S definition of metabolic syndrome, IDF: criterium involved in the IDF's definition of metabolic syndrome. 
Table II

OR of coronary heart disease in France and Belfast according to the IDF, WHO and NCEP definitions of MetS.

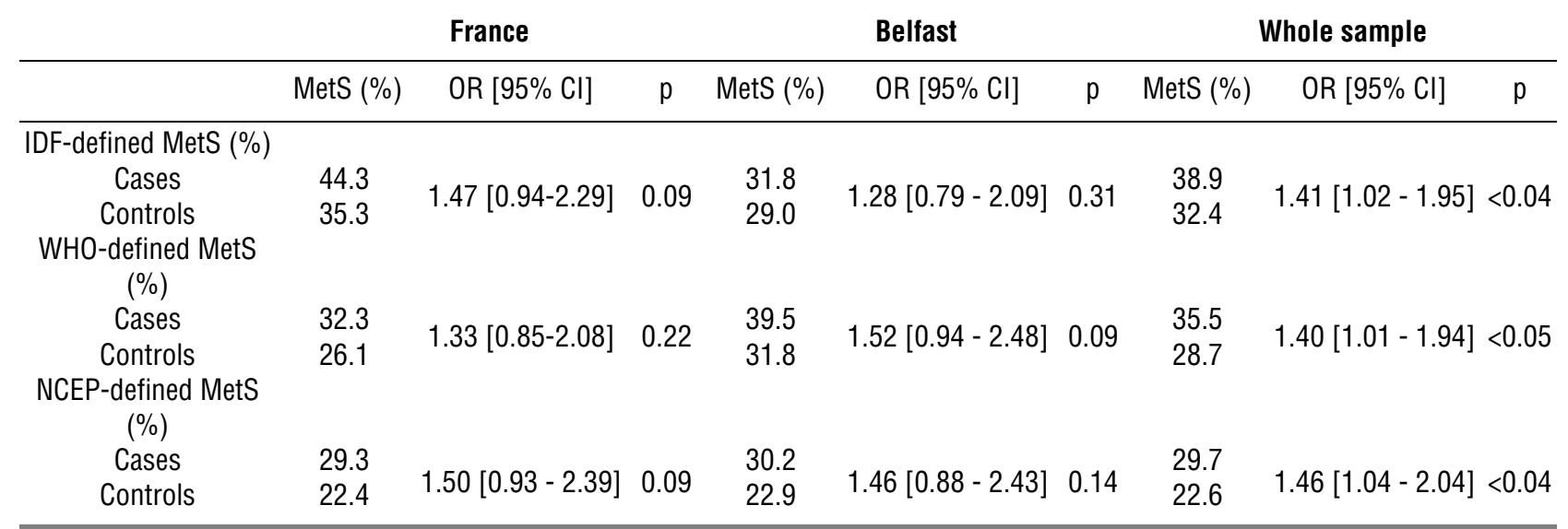

Odds-ratio and 95\% confidence interval adjusted on physical activity, smoking and drinking habits. Cases and controls are matched for age, recruitment centre and recruitment date.

Acknowledgements - We thank the following organisations which allowed the recruitment of the PRIME subjects: the Health screening centres organised by the Social Security of Lille (Institut Pasteur), Strasbourg, Toulouse and Tourcoing; Occupational Medicine Services of Haute-Garonne, of the Urban Community of Strasbourg; the Association Interentreprises des Services Médicaux du Travail de Lille et environs; the Comité pour le Développement de la Médecine du Travail; the Mutuelle Générale des PTT du Bas-Rhin; the Laboratoire d'Analyses de l'Institut de Chimie Biologique de la Faculté de Médecine de Strasbourg; the Department of Health (NI) and the Northern Ireland Chest Heart and Stroke Association.

\section{References}

1. Gorter PM, Olijhoek JK, van der Graaf Y, et al. Prevalence of the metabolic syndrome in patients with coronary heart disease, cerebrovascular disease, peripheral arterial disease or abdominal aortic aneurysm. Atherosclerosis 2004;173:363-9.

2. McNeill AM, Rosamond WD, Girman CJ, et al. Prevalence of coronary heart disease and carotid arterial thickening in patients with the metabolic syndrome (The ARIC Study). Am J Cardiol 2004;94:1249-54.

3. McNeill AM, Rosamond WD, Girman CJ, et al. The metabolic syndrome and 11-year risk of incident cardiovascular disease in the atherosclerosis risk in communities study. Diabetes Care 2005;28:385-90.

4. Hunt KJ, Resendez RG, Williams K, Haffner SM, Stern MP. National Cholesterol Education Program versus World Health Organization metabolic syndrome in relation to all-cause and cardiovascular mortality in the San Antonio Heart Study. Circulation 2004;110:1251-7.

5. Girman CJ, Rhodes T, Mercuri M, et al. The metabolic syndrome and risk of major coronary events in the Scandinavian Simvastatin Survival Study (4S) and the Air Force/Texas Coronary Atherosclerosis Prevention Study (AFCAPS/TexCAPS). Am J Cardiol 2004;93:136-41.

6. Ford ES. The metabolic syndrome and mortality from cardiovascular disease and all-causes: findings from the National Health and Nutrition Examination Survey II Mortality Study. Atherosclerosis 2004;173:309-14.
7. Malik S, Wong ND, Franklin SS, et al. Impact of the metabolic syndrome on mortality from coronary heart disease, cardiovascular disease, and all causes in United States adults. Circulation 2004;110:1245-50.

8. Lawlor DA, Smith GD, Ebrahim S. Does the new International Diabetes Federation definition of the metabolic syndrome predict $\mathrm{CHD}$ any more strongly than older definitions? Findings from the British Women's Heart and Health Study. Diabetologia 2006;49:41-8.

9. Dekker JM, Girman C, Rhodes T, et al. Metabolic syndrome and 10-year cardiovascular disease risk in the Hoorn Study. Circulation 2005;112:666-73.

10. Sattar N, Gaw A, Scherbakova O, et al. Metabolic syndrome with and without C-reactive protein as a predictor of coronary heart disease and diabetes in the West of Scotland Coronary Prevention Study. Circulation 2003;108:414-9.

11. Lakka HM, Laaksonen DE, Lakka TA, et al. The metabolic syndrome and total and cardiovascular disease mortality in middle-aged men. JAMA 2002;288:2709-16.

12. Isomaa B, Almgren $\mathrm{P}$, Tuomi $\mathrm{T}$, et al. Cardiovascular morbidity and mortality associated with the metabolic syndrome. Diabetes Care 2001;24:683-9.

13. Alberti KG, Zimmet P, Shaw J. The metabolic syndrome-a new worldwide definition. Lancet 2005;366:1059-62.

14. Laaksonen DE, Lakka HM, Niskanen LK, et al. Metabolic syndrome and development of diabetes mellitus: application and validation of recently suggested definitions of the metabolic syndrome in a prospective cohort study. Am J Epidemiol 2002;156:1070-7.

15. Executive Summary of The Third Report of The National Cholesterol Education Program (NCEP) Expert Panel on Detection, Evaluation, And Treatment of High Blood Cholesterol In Adults (Adult Treatment Panel III). JAMA 2001;285:2486-97.

16. Ducimetiere P, Ruidavets JB, Montaye M, Haas B, Yarnell J. Five-year incidence of angina pectoris and other forms of coronary heart disease in healthy men aged 50-59 in France and Northern Ireland: the Prospective Epidemiological Study of Myocardial Infarction (PRIME) Study. Int J Epidemiol 2001;30:1057-62.

17. Yarnell JW. The PRIME study: classical risk factors do not explain the severalfold differences in risk of coronary heart disease between France and Northern Ireland. Prospective Epidemiological Study of Myocardial Infarction. QJM 1998;91:667-76. 